\title{
A NATIONAL PARK IN NORTHERN RHODESIA
}

By a Proclamation dated 20th April, 1950, the Governor of Northern Rhodesia has established a National Park, to bc known as the Kafue National Park.

This new park covers some 8,650 square miles roughly in the eentral Kafue basin, betwecn latitudes $14^{\circ}$ and $16^{\circ} 40^{\prime} \mathrm{S}$. It contains a wide range of country from the comparatively dry sandy lands of the south to the big rivers, swamps, and heavy timber of the northern section. 'The magnificent Kafue River dominates the whole central portion, adding scenic beauty to the attraction of wild life.

The park contains representatives of most species of the fauna of Northern Rhodesia. Primates are represented by the Rhodesian Baboon, the Vervet Monkey, and the Greater and Lesser Night-Apes. There are Elephant and Black Rhinoceros, Buffalo, Lion, Leopard, Cheetah, and numbers of the smaller carnivora. Antelope include Eland, Sable, Roan, Lichtenstein's Hartebeest, Blue Wildebeest, Kudu, Defassa Waterbuck, Bushbuck, Reedbuck, Puku, Impala, Oribi, Common, Blue, and Yellow-backed Duikers, Klipspringer, and Sharpe's Steinbuck. There are Red Lechwe and Sitatunga in the Busango Swamp in the north, Hippopotamus in numbers in the Kafue and its larger tributaries. Zebra are common, Warthog and Bushpig everywhere. Birds are abundant.

The park is uninhabited apart from ccrtain small settlements, on a limited section of the Kafue River, belonging to the indigenous Africans under their tribal chief Kayingu. These people must be accorded their traditional local hunting rights, but such will affect only a small fraction of the whole vast wild area.

In parts the park is infested with tsetse fly and the central portion, suspected of sleeping sickness, is unlikely to be opened to human traffic for a long time. It is proposed also that the whole park should be closed to the public for an initial period of five years, so as to give time for the fauna to inerease, and to prepare roads, camps, etc., for tourist travel. The southern portion will then be opened up first, and it is hoped that in time it will be possible for intending visitors to the park to leave the Great North Road south of Kalomo, enter the park at the southern end, and after travelling through its greater length, reach Lusaka via the Mumbwa-Lusaka Road. This will offer an additional attraction to tourists visiting the Victoria Falls.

The value of the park as a tourist attraction in the future 
is expected to be considerable, but the project is not being approached from a purely economic point of view. It is felt that its main purpose should be to fulfil an obligation to future generations and to honour responsibilities undertaken in the 1933 International Convention for the Protection of the Fauna and Flora of Africa.

\title{
WILD ELEPHANTS IN ASSAM
}

\author{
By E. P. GeE
}

Reprinted with permission from Loris, the Journal of the Ceylon Game and Fauna Protection Society

Even in this age of atomic energy and jet propulsion, the market for elephants is still strong. Their value as a means of extracting timber in thick forests, as a mode of transport in otherwise inaccessible tracts of country and for ceremonial uses has not in the least declined.

There are those who, misled by the elephants' huge size, overestimate their strength, and work them till they break down. Then they decry them as weak and delicate animals. Admittedly elephants are, size for size, about a quarter less strong than a horse and slightly weaker even than man. But with the necessary knowledge of their habits in their wild state, and with proper care and attention, these sagacious and docile creatures will perform a great variety of tasks and get through an enormous amount of heavy work, resulting in an appreciable saving of man-power and complicated mechanical devices.

The elephants' services to mankind have long been fully appreciated. And the necessity of maintaining the stock of wild animals at a reasonable and safe level, and of controlling the otherwise indiscriminate catching operations and shooting for ivory, led our forefathers to pass the Elephants' Preservation Act. Under this Government of India Act of 1879, it was decreed that no wild elephant shall be killed or captured unless in a person's self-defence, or because of damage being caused. Capturing and shooting were to be permitted by licence only, to be granted by District Magistrates. Local Governments were empowered from time to time to make rules, consistent with the above Act, to regulate the conditions under which licences for capture and shooting were to be issued, and so forth. 